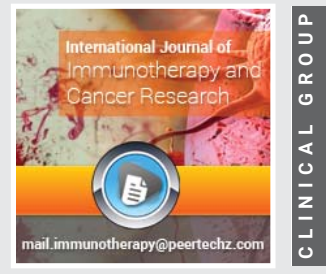

\title{
Evaluation of breast cancer regarding molecular and immunochemical markers
}

\section{Sally Ahmad Sabra' ${ }^{1}$, Abir Adel Saad ${ }^{1}$, Nadia Ahmad Abd El Moneim², Mahmoud Abd El Atty Hemida ${ }^{3}$, Nermine Moussa ${ }^{1}$ and Medhat Haroun ${ }^{1 *}$}

1Department of Biotechnology, IGSR, Alexandria University, Egypt

${ }^{2}$ Department of Cancer Management and Research, Medical Research Institute, Alexandria University, Egypt

${ }^{3}$ Department of Surgery, Medical Research Institute, Alexandria University, Egypt
Received: 03 January, 2020

Accepted: 19 February, 2020

Published: 20 February, 2020

*Corresponding author: Medhat Haroun, Professor, Department of Biotechnology, Alexandria University, Institute of Graduate Studies \& Research,163, Horreya Avenue, Chatby 21526, P.O. BOX: 832, Alexandria, Egypt, Tel: +203-5935003; +201003332740; Fax: +203-4285792; E-mail: mharounag@alexu.edu.eg; mharounag@yahoo.com

Keywords: Breast cancer; RAPD-PCR; Marker

ORCiD: https://orcid.org/0000-0002-3511-7765

https://www.peertechz.com

Check for updates

\begin{abstract}
Early-stage cancer recognition could improve awareness and treatment strategies. Twenty four breast cancer affected individuals had their DNA isolated from malignant tissues and from blood. DNA was then amplified by RAPD with six different ten-mer primers. RAPD-PCR yields were electrophoresed on a $1.5 \%$ agarose gel and visualized using ethidium-bromide staining. Only two out of the selected RAPD data have exhibited distinguishable polymorphic markers between cancerous and normal tissues. Enzyme-Linked Immunosorbent Assay (ELISA) was used for the determination plasma immunoglobulins (IgG, IgA and IgM) in patient samples preoperatively, postoperatively and after six cycles of chemotherapy treatment. Thirty age- matched normal females were examined for IgA, IgG and IgM by ELISA. Specifically, results showed that normal females had mean IgG, IgA and IgM concentrations of $9.80 \mathrm{mg} / \mathrm{ml}, 2.56 \mathrm{mg} / \mathrm{ml}$, and $1.75 \mathrm{mg} / \mathrm{ml}$ respectively while malignant patients preoperatively had mean concentration of $9.89 \mathrm{mg} / \mathrm{ml}, 2.92 \mathrm{mg} / \mathrm{ml}$ and $2.02 \mathrm{mg} / \mathrm{ml}(\mathrm{P}<0.727, \mathrm{P}<0.001$ and $\mathrm{P}<0.001)$ respectively. Moreover, analysis of the data revealed that patient plasma samples concentrations of $\mathrm{lgG}$, IgA and $\mathrm{IgM}$ postoperatively were $7.9 \mathrm{mg} / \mathrm{ml}, 1.96 \mathrm{mg} / \mathrm{ml}$ and $1.36 \mathrm{mg} / \mathrm{ml}(\mathrm{P}<0.001)$ respectively whereas, their concentrations improved to normal levels when chemotherapy was ceased. Bovine Serum Albumin (BSA) was chosen as a goal to minimize cross linking and investigate differences in immunoglobulin concentrations. On the other hand, the mean levels of IgA and IgM in patient plasma samples preoperatively after refining from antibody binding process that interfere with BSA were measured to be $2.53 \mathrm{mg} / \mathrm{ml}$ and $1.72 \mathrm{mg} / \mathrm{ml}$ respectively demonstrating that there were no statistical significance of the difference between IgA and IgM concentrations in malignant patients and healthy females. Hence, this study aimed to assess the prevalence of cross reactivity with BSA that might be used as a potent marker for patients with breast cancer.
\end{abstract}

\section{Introduction}

Breast cancer is ranking the first cause of mortality after urinary bladder tumors and malignant lymphomas [1]. A previous study showed that $5-10 \%$ of the cases of breast cancer in women can be attributed to inheritance, whereas 90-95\% are sporadic, i.e., cases that appear randomly and are not predetermined genetically [2]. Accomplishment of cancer is predictable as a multistep development of the infection where cellular modifies may cause undesired reactivity related to the uncontrolled growth and division of cells. Many critical mutations are required to convert a normal cell into a malignant cell. Malignant tumor developing is a several stages out growth that involves genetic alterations such as activating of oncogene and inactivation of tumor suppressor genes [3].
The most commonly engaged receptors and growth factors in human breast cancer are members of the epidermal growth factor receptor subfamily of tyrosine kinase receptors. The type I subfamily comprises HER-2, HER-3, and HER-4 [4]. These receptors assign a common molecular design; they all seize a large glycosylated extracellular ligand-binding domain, a single hydrophobic transmembrane domain and a cytoplasmic tyrosine kinase domain. HER-2 (also known as neu) is a protooncogene which encodes a $185-\mathrm{kD}$ a tyrosine kinase glycoprotein. Amplification of the HER-2 gene acts an important task in breast cancer pathogenesis [5]. Furthermore, amplification or over-expression of the HER-2 oncogene is associated with a poor disease free survival rate in infected individuals with axillary node-positive breast cancer [6]. Large exertion have been dedicated to unravel these genetic modification and 
to find affiliations between specific genetic revision and the clinical or pathological characteristics of the tumor. There has been quick progression of the accessible method to categorize new genetic modifications; technical advancement will also place the detection of genetic alterations in breast carcinomas within the clutch of usual clinical testing. As tumor behavior is largely determined by this genetic modification, it is expected that clinical decisive manner will be increasingly influenced by awareness of the genetic shuffling-up of a tumor. In breast cancer, the main genetic modifications are amplification of approximately ten oncogenes and inactivation of an unknown number of tumor suppressor genes [7]. In this study, the random amplified polymorphic DNA (RAPD) technique, a simple PCR-based assay system was used to detect genomic instability the verification for immune initiation to cancer in human beings, recognized in part by the detection of autoantibody against a number of intracellular and surface antigens in affected role with different neoplasm types. The detection of tumor sector antigens that elicit an antibody response may have value in cancer screening, diagnosis or prediction. Such antigens may also have utility in immunotherapy against the disease. Response to specificity of an observed humoral or cellular immunity to malignant cells has always been the critical concern in human cancer immunopathology [8]. A lot of efforts have been focused so far on developing a strict association between distinct autoimmunity and cancer, on one script, and the mien of autoimmune response in affected role with solid tumors or malignancies. On the other, this relationship can be ascribed to different reasons: a genetic and/or immunological susceptibility; oncogene activation and/or tumor suppressor gene modification with an abnormal expression of the relevant yields or atypical conditions common to both autoimmunity and cancer, such as an inherited or attained immunodeficiency [9]. Antibodies, which bind other protein, may add another aspect to the asymmetrical immunity of individual patients with abnormal mass of tissue or cancer. Deviation in immune reactivity and a limited window for the tenacity of antibodies to various epitope may account for such critical failure. The present study aims to investigate the genetic alterations in breast cancer tissue compared to the genomic blood DNA of the same patient and to characterize distinct changes in patterns of immunoglobulin levels in breast cancer patients. Bovine serum albumin is one of the most broadly considered proteins; its structure is identified and its antigenic characteristics have been identified in several works $[10,11]$. In our study, we have therefore designed to address heterophile antibody interference in our enzyme-linked immunosorbent assay detection and to propose scheme for resolving this research question. We aimed to evaluate using enzyme-linked immunosorbent assay whether antibody that interact with Bovine serum albumin present any diagnostic significance as a risk of exposure factor for breast cancer. Furthermore, the sensitivities of immunochemical assay for antibody to breast cancer affected role may be enhanced by counting antigens as Bovine serum albumin. To evaluate the potential of Bovine serum albumin contribution to breast cancer, we examined the specifity of antibodies in breast cancer patient plasma samples in breast cancer tissues. Even as there is growing interest in

against Bovine serum albumin by preabsorption, clarification and quantification using enzyme-linked immunosorbent assay [10-13].

\section{Materials and methods}

\section{Patient participants}

Informed consent was acquired personally by a health professional for all individuals prior to their addition in this report and the use of tumor tissue and plasma samples for scientific studies, which was approved by the Local Ethical Committee. The present retrospective study included 24 female breast cancer patients recently diagnosed before any treatment with mean age 50 years old. They were collected from Experimental and Clinical Surgery Department and from Cancer Management and Research Department at Medical research Institute; Alexandria University from November 2018 to December 2019. All individual patients did not obtain any previous chemotherapy treatment. Fine Needle Aspiration Cytology (FNAC) was done for every breast mass to confirm diagnosis of malignancy (Table 1). Patients were subjected to modified radical mastectomy, obtain combination FAC chemotherapy (5-Flourouracil $500 \mathrm{mgm} / \mathrm{m}^{2}$, Adriamycin $50 \mathrm{mgm} / \mathrm{m}^{2}$, Cyclophosphamide $500 \mathrm{mgm} / \mathrm{m}^{2}$ for 6 cycles) and they were followed up clinically for six months. Control group included 30 normal healthy females matched in age and menopausal status with the patients group. A sample of tumor tissue from the diseased breast was obtained immediately

Table 1: Clinicopathological parameters and general characterization of patients.

\begin{tabular}{|c|c|c|}
\hline Parameter & Number & Percentage (\%) \\
\hline $\begin{array}{l}\text { Menopausal status } \\
\text { Pre menopause } \\
\text { post menopause }\end{array}$ & $\begin{array}{c}7 \\
17\end{array}$ & $\begin{array}{l}29.2 \\
70.8\end{array}$ \\
\hline $\begin{array}{c}\text { Tumor type } \\
\text { Invasive ductual carcinoma } \\
\text { Invasive lobular carcinoma } \\
\text { Invasive vascular carcinoma } \\
\text { Itraductual carcinoma }\end{array}$ & $\begin{array}{c}21 \\
1 \\
1 \\
1\end{array}$ & $\begin{array}{c}87.5 \\
4.2 \\
4.2 \\
4.2\end{array}$ \\
\hline $\begin{array}{c}\text { Histological grade } \\
\text { I } \\
\text { II } \\
\text { III } \\
\text { High grade }\end{array}$ & $\begin{array}{c}1 \\
19 \\
3 \\
1\end{array}$ & $\begin{array}{c}4.2 \\
79.2 \\
12.5 \\
4.2\end{array}$ \\
\hline $\begin{array}{c}\text { Tumor size } \\
<10 \\
10-14 \\
>14\end{array}$ & $\begin{array}{c}13 \\
2 \\
9\end{array}$ & $\begin{array}{c}54.2 \\
8.3 \\
37.5\end{array}$ \\
\hline $\begin{array}{c}\text { LN involvement } \\
\text {-ve } \\
\text { +ve }\end{array}$ & $\begin{array}{c}9 \\
15\end{array}$ & $\begin{array}{l}37.5 \\
62.5\end{array}$ \\
\hline $\begin{array}{c}\text { ER status } \\
\text {-ve } \\
\text { +ve } \\
\text { strongly positive }\end{array}$ & $\begin{array}{l}7 \\
8 \\
9\end{array}$ & $\begin{array}{l}29.2 \\
33.3 \\
37.5\end{array}$ \\
\hline $\begin{array}{c}\text { PR status } \\
\text {-ve } \\
\text { +ve } \\
\text { strongly positive }\end{array}$ & $\begin{array}{c}10 \\
8 \\
6\end{array}$ & $\begin{array}{l}41.7 \\
33.3 \\
25.0\end{array}$ \\
\hline $\begin{array}{c}\text { Her2-neu status } \\
\text {-ve } \\
\text { +ve } \\
\text { strongly +ve }\end{array}$ & $\begin{array}{c}14 \\
6 \\
4\end{array}$ & $\begin{array}{l}58.3 \\
25.0 \\
16.7\end{array}$ \\
\hline
\end{tabular}

Citation: Sabra SA, Saad AA, Abd El Moneim NA, El Atty Hemida MA, Haroun M, et al. (2020) Evaluation of breast cancer regarding molecular and immunochemical markers. Int J Immunother Cancer Res 6(1): 001-009. DOI: https://dx.doi.org/10.17352/2455-8591.000021 
after surgery and kept at $-80^{\circ} \mathrm{C}$ until use for investigation. Three whole blood samples were collected on citrate, first sample was taken just before surgery, second sample was taken postoperatively (before chemotherapy) and the third sample was taken after six cycles of chemotherapy. Plasma was collected from the three fresh blood samples and from controls, and then samples were kept at $-80^{\circ} \mathrm{C}$ until use.

\section{DNA isolation and RAPD-PCR assay}

Six random primers (decanucleotide GC-rich) were used to score the alterations in the isolated tumor DNA in comparison with corresponding blood DNA from the same patient. These primers have been reported previously by Singh, K.P. and Roy, D. 2001 [15]. The sequences of the used primers are shown in Table 2. The primers were synthesized by Biobasic. DNA of tumor tissue and corresponding blood DNA of the same patient before surgery and after chemotherapy were compared with each other to insure that the alterations found in tumor DNA are of cancerous origin. Genomic DNA extraction from tumor tissue was achieved using the genomic DNA purification kit Ko 512 (100 preps) that purchased from Fermentas; DNA from whole blood was isolated according to Sambrook et al 1989 [15]. Polymerase Chain Reaction (PCR) was followed according to Singh, K.P. and Roy, D.2001 [14]. Go Taq ${ }^{\circledR}$ Green PCR Master Mix (Promega) was added to DNA samples and each primer (20ng/ $\mu \mathrm{l})$. Finally; the samples were loaded in thermocycler $\left(\right.$ Peqlab $\left.^{\circledR}\right)$ with heated lid. Primarily, samples were heated for 1 cycle $\left(3.5 \mathrm{~min}\right.$ at $92^{\circ} \mathrm{C}$ for denaturation, $1 \mathrm{~min}$ at $34^{\circ} \mathrm{C}, 2 \mathrm{~min}$ at $72^{\circ} \mathrm{C}$ ) and then cycled 44 times at $92^{\circ} \mathrm{C}$ for $1 \mathrm{~min}, 34^{\circ} \mathrm{C}$ for $1 \mathrm{~min}$ and $72^{\circ} \mathrm{C}$ for $2 \mathrm{~min}$ followed by a final extension cycle of $15 \mathrm{~min}$ at $72^{\circ} \mathrm{C}$. The yield of PCR amplification was resolved by electrophoresis on $1.5 \%$ agarose gel and then visualized by ethidium bromide staining. A negative control reaction, without genomic DNA was run with every set of samples to validate that no contaminating nucleic acid was present in the reactions [16].

Table 2: Primers utilized for RAPD analysis.

\begin{tabular}{|c|c|}
\hline Primer & Sequences \\
\hline OPC-04 & 5'-CCGCATCTAC-3' \\
\hline OPC-05 & 5'-GATGACCGCC-3' \\
\hline OPC-16 & 5'-CACACTCCAG-3' \\
\hline OPC-03 & 5'-GGGGGTCTTT-3' \\
\hline OPC-06 & 5'-GAACGGACTC-3' \\
\hline OP A-16 & 5'-AGCCAGCGAA-3' \\
\hline
\end{tabular}

\section{Immunoglobulin measurement by enzyme-linked im-} munosorbent assay (ELISA)

Anti-human immunoglobulin G, A, M (product \# I8635, SAB3701232, 10140 respectively) raised in rabbit, Antihuman IgA antibody, IgG, IgM HRP conjugate (product \# AP120P), human IgG, A, M (product \# I4506, 401098, I8260 respectively) and tertramethylbenzidine were all purchased from Sigma (Sigma-Aldrich company Ltd, UK) and other chemicals were obtained from BDH (VWR International Ltd, UK). Coating antibody was diluted 1 in 1000 in $1 x$ coating buffer
(0.02 M Tris- $\mathrm{HCl}, 1.5 \mathrm{M} \mathrm{NaCl} \mathrm{pH} \mathrm{9.0)} \mathrm{and} \mathrm{100 \mu l} \mathrm{was} \mathrm{added}$ to each of the wells of ELISA plate [17,18]. After overnight incubation at $4^{\circ} \mathrm{C}$ the plate was washed 4 times with PBST20 $(0.1 \%(\mathrm{w} / \mathrm{v})$ [Tween 20 in $1 \mathrm{x}$ PBS (phosphate buffered saline; $0.25 \mathrm{M} \mathrm{NaCl}, 0.0268 \mathrm{M} \mathrm{KCl}, 0.081 \mathrm{M} \mathrm{Na}_{2} \mathrm{HPO} 4$ and 0.0146 $\left.\mathrm{M} \mathrm{KH}_{2} \mathrm{PO}_{4}\right)$ ]. Sites unoccupied by antibody were blocked by addition of $5 \%(\mathrm{w} / \mathrm{v})$ dried skimmed milk in PBS for $1 \mathrm{~h}$ at room temperature followed by washing 6 times with PBST20. The human serum samples were initially diluted 1 in 2000 in 1x PBS, and 2 fold serial dilutions subsequently performed on the plate. Diluted samples were allowed to bind to the first antibody and the plate was then washed 6 times in PBST20 $[7,8]$. Anti-human IgA antibody, IgG, and IgM HRP conjugate

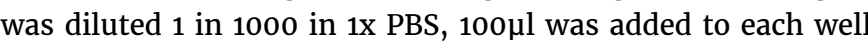
of the microtiter plate, incubated at room temperature for 1 $\mathrm{h}$ and then washed 6 times in PBST20. The amount of bound second antibody was determined by adding $200 \mu$ of the substrate solution [tetramethylbenzidine $6 \mathrm{mg} / \mathrm{ml}$ in $0.1 \mathrm{M}$ sodium acetate, buffer $\mathrm{pH}$ 6.0] to each well. After incubation, in the dark at room temperature for $20 \mathrm{~min}$, the reaction was stopped by adding $50 \mu \mathrm{l}$ of $10 \%(\mathrm{w} / \mathrm{v}) \mathrm{H}_{2} \mathrm{SO}_{4}$ to each well. The optical density of each sample was read with an ELISA plate reader with a 450-nm filter. A standard curve was constructed by plotting absorbance against concentration for the standard solutions and the concentration of immunoglobulin $(\mathrm{mg} / \mathrm{ml})$ in the samples was determined $[12,13]$.

\section{Purification of patient plasma samples from the cause of antibodies that cross-react with BSA}

Bovine serum albumin, $56 \mu \mathrm{l}$, at a concentration of $50 \mathrm{mg} / \mathrm{ml}$ solution in $1 \mathrm{x}$ PBS, pH 7.2 were mixed with $200 \mu \mathrm{l}$ of individual plasma samples (diluted 1 in 10) to diminish further crosslinking to bovine serum albumin. The absorption was carried out for $1 \mathrm{~h}$ at $37^{\circ} \mathrm{C}$, followed overnight at $4^{\circ} \mathrm{C}$. Individual plasma samples were purified by centrifugation at 10000x $\mathrm{g}$ for 20 min at $4^{\circ} \mathrm{C}$ prior to analyzing [19]. The absorption of individual plasma with Bovine serum albumin was able to remove preadsorbed proteins completely. Hence, the concentration of immunoglobulin in each of these plasma samples was determined by ELISA as described above.

\section{Statistical analysis}

The arithmetic mean for each group was calculated and the variation or variability in each group was represented by the Standard Deviation (SD). Data are presented as means with their standard deviation. Differences among the control, patients treated and non treated groups were assessed by Student's t-test to analyze specific differences between means.

\section{Results}

Six random ten-mer primers were used to analyze instability in the genome of breast cancer tissues using RAPD-DNA fingerprinting. Of these six primers, three of them produced similar amplification patterns in all the DNA samples (data not shown). The remaining three primers detected genetic alterations in the tumor DNA. RAPD products were resolved on agarose (1.5\%). Amplified products resolved 
on agarose gel were visualized by ethidium bromide staining. Upon experiencing opco4 primer, the RAPD fingerprint showed substantial difference between tumor DNA compared to blood DNA of the same patient. Out of 24 examined breast cancer cases, 10 cases were found to have a deletion of about 1078 b.p. $(42 \%)$ in their tumor DNA. 8 cases were found to have a deletion of about 872 b.p. (33\%) in their tumor DNA, while both deletions were detected in 2 cases $(8 \%)$ of patients as shown in Figures 1-3.

\section{RAPD's analysis}

Searching for point mutations within oncogenes sequences involved in tumorgensis, 6 different 10-mer RAPD primers previously reported have been used. Only 2 out of the selected primers have showed a clear and specific polymorphism to tumor tissue. These 2 primers showed high identity percentage with some exons of 2 different human oncogenes. For V-myc (Homo. Sapiens V-myc myelocytomatosis viral oncogene homolog (avian) (myc) gene, OPC-05 primer was used. The 3 '-end of this primer was identical with region 450 of V-myc CDNA. A polymorphic band of $350 \mathrm{bp}$ was found to be deleted in $42 \%$ of patients' tumor DNA and found in their blood DNA (Figure 4). For HER4 (H. Sapiens V-erb-a erthroblastic leukeamia viral oncogene homolog 4 (avian) (ERBB4or HER4), several 10-mer primers were found to be identical to different exons of HER4 gene. Among these primers, OPC-16 primer has showed a polymorphic band among the blood DNA and tumor DNA of the same patient. This polymorphic band (30obp) was present in blood DNA and absent in $25 \%$ of tumor DNA as shown in Figure 5.

\section{Human Immunoglobulin measurement by ELISA}

Plasma samples were analyzed for immunoglobulin G, A and $M$ using enzyme-linked immunosorbent assay because they are proven to be implicated in autoimmune reactions, constitute nearly all antibody content of the plasma. All patients had their plasma immunoglobulin IgG, IgA and IgM measured by ELISA preoperatively, postoperatively (before chemotherapy) and after six cycles of chemotherapy. Also immunoglobulin concentrations were measured in control group matching in age with the individual patients group.

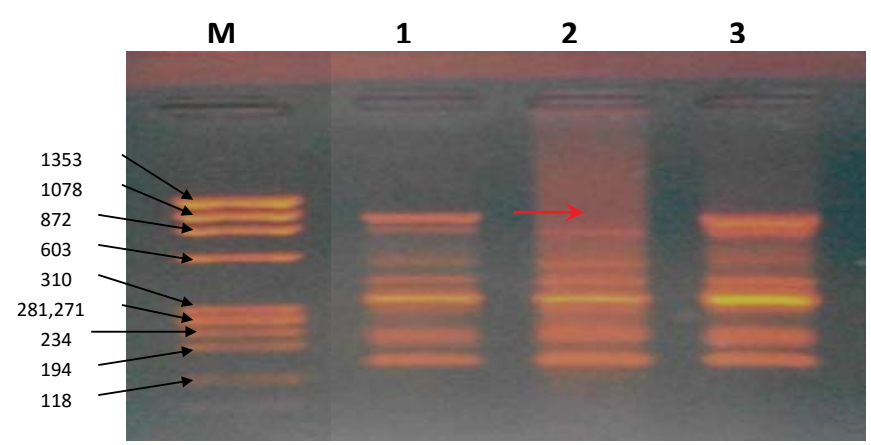

Figure 1: (RAPD profile of opco4 primer showing deletion of 1078 b.p. band). M represents marker ( $\varphi$ X 174/ Hae III DNA marker), Lanes (1-3) represent blood sample, tumor tissue and blood after chemotherapy respectively for patient no. 1 where a deletion of about 1078 b.p was detected in tumor DNA.(red arrow shows the deleted band).

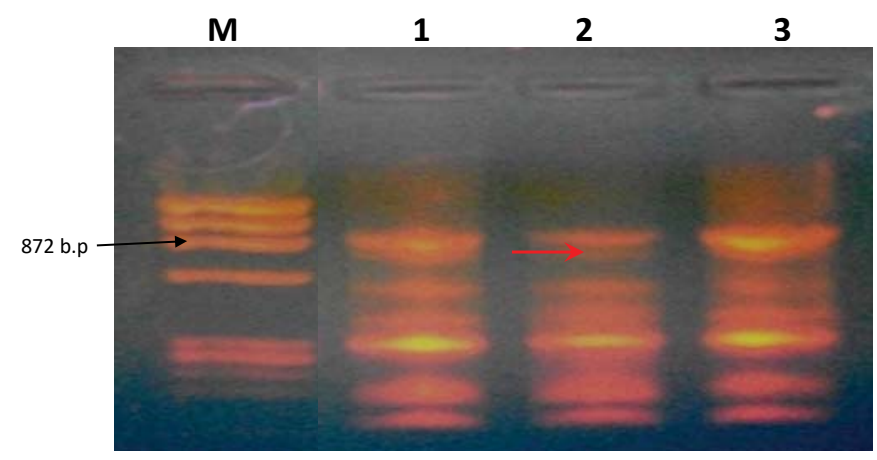

Figure 2: (RAPD profile of opco4 primer showing deletion of 872 b.p. band). $M$ represents marker ( $\varphi \times 174$ / Hae III DNA marker), Lanes (1-3) represent blood sample, tumor tissue and blood after chemotherapy of patient no.14 respectively where a deletion of about 872 b.p was detected in tumor DNA.( Red arrow shows the deleted band).

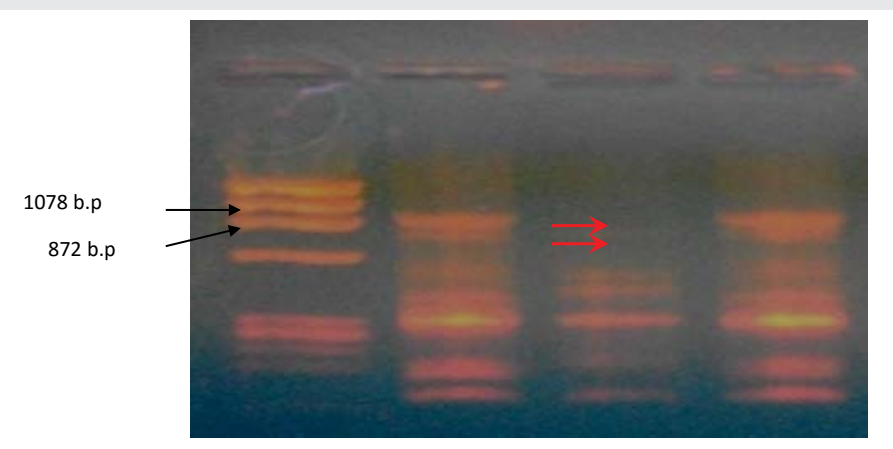

Figure 3: (RAPD profile of opco4 primer showing deletion of both 1078 b.p. and 872 b.p. bands). M represents marker ( $\varphi \times 174$ / Hae III DNA marker), Lanes (13) represent blood before surgery, tumor tissue and blood after chemotherapy respectively of patient no. 13 where a deletion of 1078 b.p and 872 b.p was detected in tumor DNA. (Red arrows show the deleted bands).

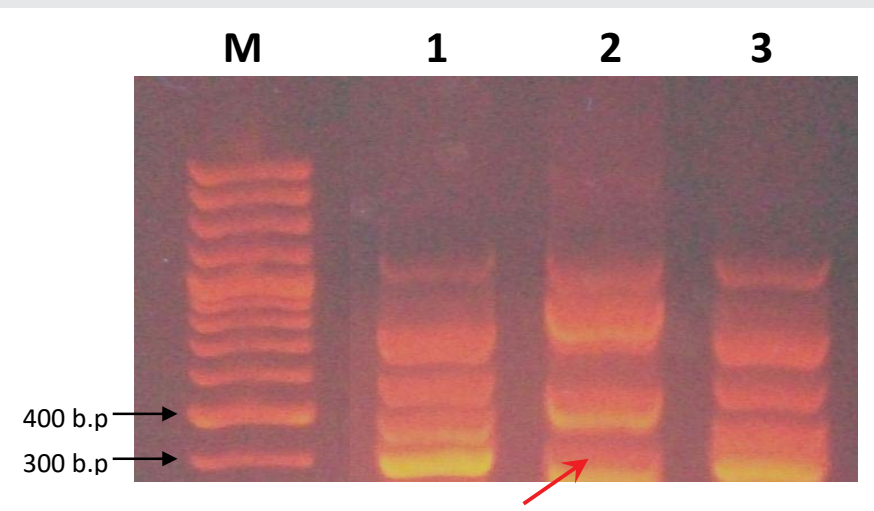

Figure 4: (RAPD profile of opco5 primer showing deletion of 350 b.p. band). M represents marker (Gene ruler TM 100 bp plus DNA leader, ready to use purchased from Fermentas), lanes (1-3) represent blood before surgery, tumor tissue and blood after chemotherapy respectively of patient no. 4 where there is deletion of 350 b.p. band in tumor DNA.( Red arrow shows the deleted band).

Plasma immunoglobulin A and $M$ concentrations were evaluated earlier by enzyme-linked immunosorbent assay (mean \pm SD) and showed that preoperatively breast cancer patients had a mean concentrations of immunoglobulin $A$ and $M$ of $2.92 \pm 0.19 \mathrm{mg} / \mathrm{ml}$ and $2.02 \pm 0.14 \mathrm{mg} / \mathrm{ml}$, respectively which were higher than healthy individuals $(2.56 \pm 0.25 \mathrm{mg} / \mathrm{ml}$ and $1.75 \pm 0.14$ $\mathrm{mg} / \mathrm{ml}$ ). Tables 3,4 represented a significant increment in both blood plasma immunoglobulin $\mathrm{A}$ and $\mathrm{M}$ concentration 


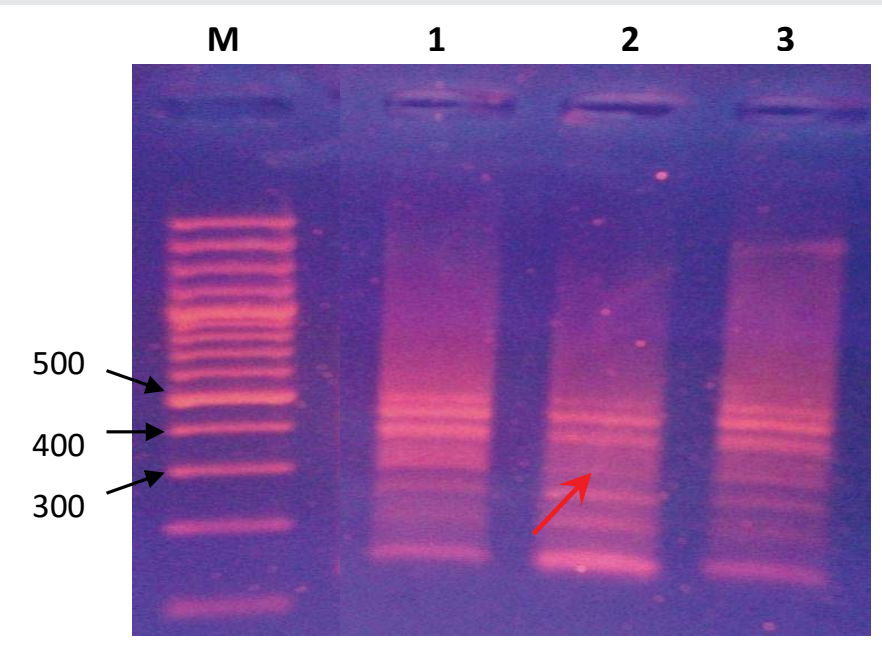

Figure 5: (RAPD profile of opc16 primer showing deletion of 350 b.p. band). M represents marker (Gene ruler ${ }^{\mathrm{TM}} 100$ bp plus DNA leader, ready to use purchased from Fermentas), Lanes (1-3) represent blood before surgery, tumor tissue and blood after chemotherapy respectively of patient no.13 where there is deletion of 300 b.p. in tumor tissue. (Red arrow shows the deleted bands).

of preoperatively group compared to control group ( $\mathrm{p}<0.001)$. However, the mean level of plasma immunoglobulin $\mathrm{G}$ (Table 5) of preoperatively group was $(9.89 \pm 0.98 \mathrm{mg} / \mathrm{ml})$ and there was no significant difference between preoperatively group and control group $(\mathrm{p}<0.727)$. Moreover, data showed that the concentrations of plasma immunoglobulin $\mathrm{G}(7.90 \pm 0.72 \mathrm{mg} /$ $\mathrm{ml}$; $\mathrm{p}<0.001)$, immunoglobulin A $(1.96 \pm 0.25 \mathrm{mg} / \mathrm{ml} ; \mathrm{p}<0.001)$ and immunoglobulin $M(1.36 \pm 0.13 \mathrm{mg} / \mathrm{ml} ; \mathrm{p}<0.001)$ in breast cancer plasma patients postoperatively (before chemotherapy) were noticeably reduced but they improved to normal values when chemotherapy was discontinued and found that the plasma immunoglobulin $\mathrm{G}, \mathrm{A}$ and $\mathrm{M}$ concentrations were within the normal level after treatment with Bovine serum albumin $(9.76 \pm 0.96 \mathrm{mg} / \mathrm{ml}, 2.53 \pm 0.18 \mathrm{mg} / \mathrm{ml}$ and $1.72 \pm 0.12 \mathrm{mg} /$ $\mathrm{ml} ; \mathrm{p}<0.885, \mathrm{p}<0.641$ and $\mathrm{p}<0.424$, respectively). Enzymelinked immunosorbent assay detection was accomplished by assessing plasma samples with or without pre-absorbing with Bovine serum albumin. Plasmas from healthy individuals or breast cancer patients (preoperatively) were assigned to two groups (I and II). Each plasma sample in group I (from normal plasma individuals) was separated into two and was allocating to groups 1 and 2 and each sample in group II (from preoperatively breast cancer affected individuals) was assigned to groups 3 and 4 . Groups 1 and 3 were not pre-absorbed with Bovine serum albumin, while groups 2 and 4 were preabsorbed as previously explained in Materials and Methods. Normal individual and breast cancer plasmas were pretreated with Bovine serum albumin to investigate whether this would influence the immunoglobulin $\mathrm{A}$ and $\mathrm{M}$ concentrations assayed by ELISA. In fact, immunoglobulin $\mathrm{G}$ was barred from this test because there was a non-significant outcome in the concentrations of plasma IgG between preoperatively breast cancer patients when compared to control group. Results expressed in figures 6,7 showed that pre-absorption of plasma samples with Bovine serum albumin prior to ELISA affected both immunoglobulin A and $M$ concentrations, but that were noticeably reduced the levels of IgA and IgM in the plasma samples from cancer patients (group 4) while plasma samples from normal control individuals (group 2) were barely affected by this treatment. The quantitative analysis of plasma IgA level $($ mean \pm SD) showed that group 1 had a mean level of IgA of $(2.56 \pm 0.25 \mathrm{mg} / \mathrm{ml})$ which was lower than group 3 $(2.92 \pm 0.19 \mathrm{mg} / \mathrm{ml})$. This demonstrated a significant increase in immunoglobulin A concentration in the plasma of group 3 compared to group $1(\mathrm{p}<0.001)$. In contrast, the mean levels of immunoglobulin A in group 4 were $(2.53 \pm 0.24 \mathrm{mg} / \mathrm{ml})$ and there was no significant difference between group 4 and group $1(\mathrm{p}<0.142)$. The effect of Bovine serum albumin treatment as as a protective protein on the detection of immunoglobulin $\mathrm{A}$ in plasmas of the control group (group 2) was earlier

Table 3: Comparison between breast cancer patients and unaffected control measured by ELISA at the different periods according to plasma IgA level ( $\mathrm{mg} / \mathrm{ml})$.

\begin{tabular}{|c|c|c|c|c|}
\hline \multirow{2}{*}{ Plasma IgA } & \multirow{2}{*}{ Control } & \multicolumn{3}{|c|}{ Patients } \\
\cline { 3 - 5 } & & Before & During & After \\
\hline Range & $2.25-3.0$ & $2.20-3.30$ & $1.50-2.50$ & $2.0-2.79$ \\
\hline Mean \pm SD & $2.56 \pm 0.25$ & $2.92 \pm 0.19$ & $1.96 \pm 0.25$ & $2.53 \pm 0.18$ \\
\hline SE & 0.05 & 0.04 & 0.05 & 0.04 \\
\hline$\%$ of chg & & 14.1 & -23.4 & -1.2 \\
\hline$\%$ of chg & & & -32.9 & -13.4 \\
\hline $\mathrm{t}_{1}(p)$ & & $5.966^{*}(<0.001)$ & $8.850^{*}(<0.001)$ & $0.469(0.641)$ \\
\hline $\mathrm{t}_{2}(\mathrm{p})$ & & & $17.320^{*}(<0.001)$ & $11.662^{*}(<0.001)$ \\
\hline
\end{tabular}

\%of $\mathrm{chg}_{1}$ : Percent of change between control group and patient at the different periods.

$\%$ of $\mathrm{chg}_{2}$ : Percent of change between before and other periods in patients group.

$t_{1}$ : Student $t$-test between control group and patient at the different periods.

$t_{2}$ : Paired $t$-test between before and other periods in patients group

Table 4: Comparison between breast cancer patients and unaffected control measured by ELISA at the different periods according to plasma IgM level ( $\mathrm{mg} / \mathrm{ml})$.

\begin{tabular}{|c|c|c|c|c|}
\hline \multirow{2}{*}{ Plasma IgM } & \multirow{2}{*}{ Control } & \multicolumn{3}{|c|}{ Patients } \\
\cline { 3 - 5 } & & Before & During & After \\
\hline Range & $1.50-2.0$ & $1.50-2.30$ & $1.20-1.65$ & $1.51-1.90$ \\
\hline Mean \pm SD & $1.75 \pm 0.14$ & $2.02 \pm 0.14$ & $1.36 \pm 0.13$ & $1.72 \pm 0.12$ \\
\hline SE & 0.03 & 0.03 & 0.03 & 0.03 \\
\hline \%of chg & & 15.4 & -22.3 & -1.7 \\
\hline \%of chg & & & -32.7 & -14.9 \\
\hline $\mathrm{t}_{1}(\mathrm{p})$ & & $6.711^{\star}(<0.001)$ & $10.489^{*}(<0.001)$ & $0.806^{*}(0.424)$ \\
\hline $\mathrm{t}_{2}(\mathrm{p})$ & & & $25.886^{*}(<0.001)$ & $10.841^{\star}(<0.001)$ \\
\hline
\end{tabular}

$\%$ of chg ${ }_{1}$ : Percent of change between control group and patient at the different periods.

$\%$ of chg $_{2}$ : Percent of change between before and other periods in patients group

$t_{1}$ : Student $t$-test between control group and patient at the different periods.

$t_{2}$ : Paired t-test between before and other periods in patients group.

Table 5: Comparison between breast cancer patients and unaffected control measured by ELISA at the different periods according to plasma lgG level $(\mathrm{mg} / \mathrm{ml})$

\begin{tabular}{|c|c|c|c|c|}
\hline \multirow{2}{*}{ Plasma IgG } & \multirow{2}{*}{ Control } & \multicolumn{3}{|c|}{ Patients } \\
\cline { 3 - 5 } & & Before & During & After \\
\hline Range & $8.0-11.20$ & $8.10-12.0$ & $6.50-8.95$ & $8.0-11.71$ \\
\hline Mean \pm SD & $9.80 \pm 0.95$ & $9.89 \pm 0.98$ & $7.90 \pm 0.72$ & $9.76 \pm 0.96$ \\
\hline SE & 0.17 & 0.20 & 0.15 & 0.20 \\
\hline \%of chg & & 0.9 & -19.4 & -0.4 \\
\hline \%of chg chy $_{2}$ & & & -20.1 & -1.3 \\
\hline $\mathrm{t}_{1}(\mathrm{p})$ & & $0.351(0.727)$ & $8.085^{\star}(<0.001)$ & $0.145(0.885)$ \\
\hline $\mathrm{t}_{2}(\mathrm{p})$ & & & $11.072^{*}(<0.001)$ & $6.166^{\star}(<0.001)$ \\
\hline
\end{tabular}

$\%$ of chg ${ }_{1}$ : Percent of change between control group and patient at the different periods.

$\%$ of chg ${ }_{2}$ : Percent of change between before and other periods in patients group

$t_{1}$ : Student $t$-test between control group and patient at the different periods.

$t_{2}$ : Paired t-test between before and other periods in patients group. 


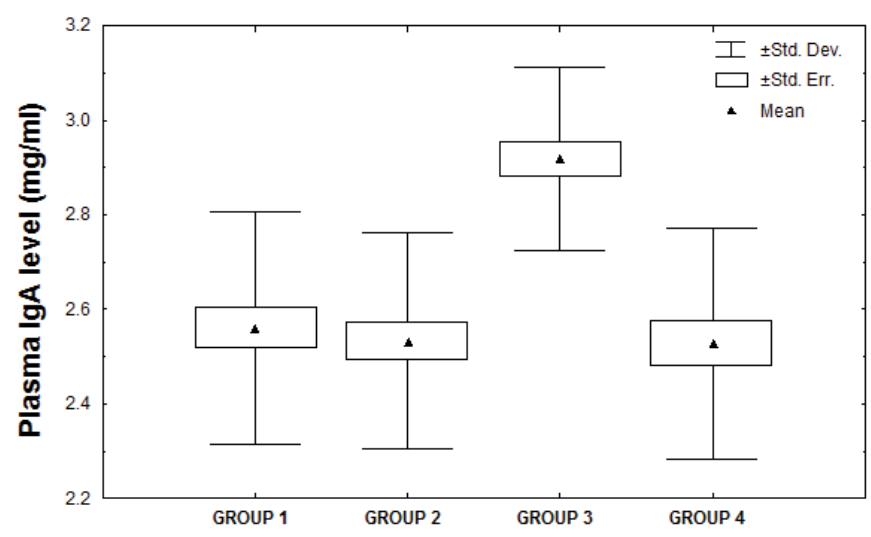

Figure 6: Effects of BSA pretreatment on plasma IgA level in preoperatively breast cancer patients (Group 3 \& 4) and healthy control (Group 1 \& 2) measured by ELISA. Comparison of average plasma IgA (mean \pm SD).

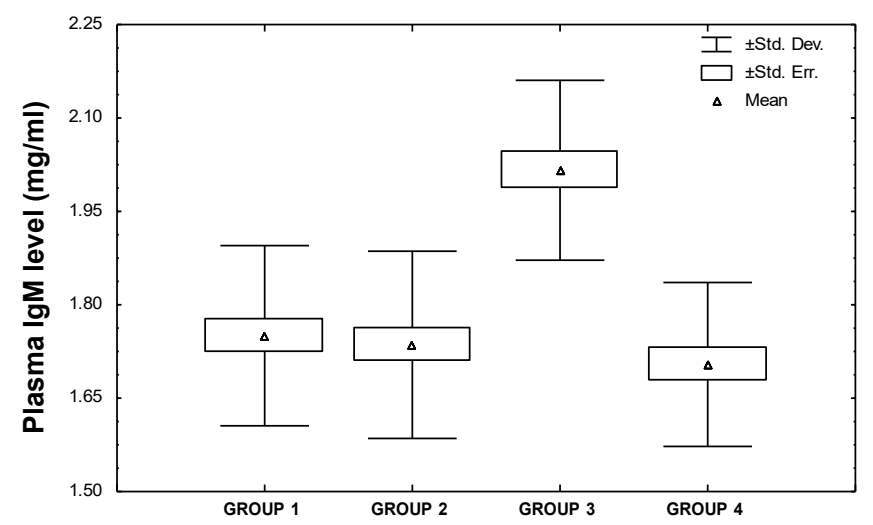

Figure 7: Effects of BSA pretreatment on plasma IgM level in preoperatively breast cancer patients (Group $3 \& 4$ ) and healthy control (Group $1 \& 2$ ) measured by ELISA. Comparison of average plasma IgM (mean $\pm \mathrm{SD}$ ).

measured and found that the IgA concentration was within the normal level after pre-absorption $(2.53 \pm 0.23 \mathrm{mg} / \mathrm{ml}$; $\mathrm{p}<0.142$ ). Conversely, after pretreatment with Bovine serum albumin the means of groups 2 and 4 were basically matching $(2.53 \pm 0.23 \mathrm{mg} / \mathrm{ml}, 2.53 \pm 0.24 \mathrm{mg} / \mathrm{ml} ; \mathrm{p}<0.42)$. The results of plasma immunoglobulin $M$ concentrations assayed from ELISA showed that the differences between normal and preoperatively breast cancer patients that were not pre-absorbed with Bovine serum albumin (groups 1 and 3 ) were significant $(1.75 \pm 0.14 \mathrm{mg} /$ $\mathrm{ml}, 2.02 \pm 0.14 \mathrm{mg} / \mathrm{ml} ; \mathrm{p}<0.001)$. Furthermore, the concentration of immunoglobulin $\mathrm{M}$ estimated with and without BSA preabsorption in normal groups (groups 1 and 2) were mostly matching $\quad(1.75 \pm 0.14 \mathrm{mg} / \mathrm{ml}, \quad 1.74 \pm 0.15 \mathrm{mg} / \mathrm{ml} ; \quad \mathrm{p}<0.220)$, whereas in the breast cancer groups (groups 3 and 4) they were significantly different $(2.02 \pm 0.14 \mathrm{mg} / \mathrm{ml}, 1.70 \pm 0.13 \mathrm{mg} /$ $\mathrm{ml} ; \mathrm{p}<0.001)$. Consequently pretreatment of plasma samples from normal individual or breast cancer patients with Bovine serum albumin may contribute towards reducing or eliminating differences in both immunoglobulin $\mathrm{A}$ and $\mathrm{M}$ specificity assayed by ELISA.

\section{Disussion}

Antibodies to tumor-associated proteins may increase the number of obtainable tumor markers for breast cancer and may be used together in a serum profile to improve sensitivity and specificity. Serum autoantibody profiling shows a potential advance for early detection and diagnosis of breast cancer. Our results reveal that RAPD is a reliable and reproducible assay that has the potential to detect a wide range of DNA damage (e.g. DNA adducts, DNA breakage) as well as mutations (point mutations and large rearrangements) and therefore can be applied to genotoxicity and carcinogenesis studies. Understanding of the genetic trial progress towards transformation from normal to malignant cell has now been approved. This hypothesis achieved by comparing the RAPD profiles obtained from healthy and malignant cells within the same person. Hence, the potential effects of study in human genetic variability have been addressed these argument questions among species $[20,21]$. In longitudinal studies of chemical or physical agents interaction with the genomic DNA may also be responsible for the DNA alterations. Therefore, changes observed in the DNA profiles such as changes in band intensity could be examined by the random amplified polymorphic DNA analysis. Consequently fragments generated by the random amplified polymorphic DNA analysis were visualized by agarose gel electrophoresis as the profile may differ due to band shifts, missing bands or visibility of new bands [22]. Therefore the changes occurring in RAPD profiles show alterations in oligo-nucleotide priming sites and activity changes of the taq DNA polymerase [16]. It is note that changes in a particular band patterns reproduce DNA structure modification in the genome from a single base changes point mutations to complex DNA alterations. In response to DNA destruction comprises hydrolysis, oxidation, alkylation, and mismatch of DNA bases which may notably interfere with the PCR steps either during denaturation, primer annealing or the polymerization step. Structural disorder may could be an important factor and so contribute to the effect on the dynamic nature of the polymerase chain reaction events. An age related disease caused by the accumulation of genomic instability in the genome and with increased risk of cancer occurrence. Exposure to ionizing radiation leads to oxidizing actions and causing disorders that created from exogenous sources and endogenous causes, particularly in the mitochondria [23]. They greatly reduce the primers annealing sensitivity to the reaction and they can reduce the DNA polymerization so obstruct the taq DNA polymerase [24]. The subsequent steps, however, involve variation in band intensity and disappearance, leading to broad DNA destruction. In the current study, a loss of an amplified product (Amplicon) may attribute to the loss of the oligonucleotide priming site due to the oxidative stress activator including superoxide and hydrogen peroxide that affect cell membrane leading to mutagenicity and carcinogenicity due to extensive DNA damage. These results may demonstrate the enhancement in deoxyribonucleic acid molecule break and repair in breast cancer patients [25]. Our finding data showed that RAPD is a sensitive technique that has the potential to detect a broad range of deoxyribonucleic acid destruction as well as mutations and it is useful to study carcinogenesis. Furthermore, the related bands produced in RAPD profile make it possible to recognize some of the molecular trials concerned in genomic disorder where DNA amplification plays a role in initiation and malignancy in cancer cells [21]. It is fairly simple to understand and to use and produces results rapidly by using 
this technique for a direct cloning and characterization of a specific target region of deoxyribonucleic acid bands which represent genetic changes specifically in breast cancer genome during tumor progression [26]. Among the genetic alterations observed in this study, no significant correlation was observed between the genetic alterations and tumor size, tumor type, tumor grade, menopausal status, estrogen receptor status, progesterone receptor status or Her 2-neu status. Taken together, we showed that (Tables 3-5) the reduction in specific antibody was not a reflection to other immunoglobulin concentration. Results are consistent and strongly support the hypothesis of the role of early immune defect in plasma cell immunoglobulin proliferation and differentiation in the pathogenesis of breast cancer [25]. Clearly, with reference to immunoglobulin $\mathrm{G}$ concentrations in early diagnosed breast cancer patients, the comparison of plasma immunoglobulin $\mathrm{G}$ concentrations in women with breast cancer compared to healthy or patient subjects with benign breast disease is in agreement with results of Dostalova et al, 1975 and Springer et al, 1976 [26-29]. Exposure to radiotherapy after surgery results in reduced secretion of immunoglobulin concentrations. Unable to induce normal antibody responses might be due to a deficient in the colony formation of antibody secretion, where cancer cells provoke many changes to normal regulatory $\mathrm{T}$-cells. However, T regulatory cells play a key role in the control of the immune response and it can damage the right generation and maturation of B-cells. Furthermore, cell-mediated cytotoxic therapy involves two major pathways of killing of cellular targets and produce deficiency in the cell-mediated tolerance [30]. These types of explanation ascribing the immunodeficiency and autoimmune response as several antibody deficiencies are associated with autoimmune disease. Overall, there is evidence for nonspecific activation of the immune system disorders in breast cancer could be related to auto-reactive B cell clones which promote initiation of autoimmune response. It is well established that cell-mediated immunity declined in several developed breast cancer individuals however, it is unsure whether this status is widespread in early breast cancer patients [31].

The humoral immune system plays a key role in the initiation and regulation of the magnificent response and removal of pathogens. It is a credible source to consider that a breast cancer may result from an alteration in the reactivity to extended autoimmune stimulation of the products secreted by exocrine glands, which themselves are modified by changes in the hormonal condition of the patient and are connected early with immune disorders [32]. Several approaches to address this issue have been developed a strict association between distinct autoimmunity and tumors [33,34]. This association can be attributed to different causes as genetic and/ or immune susceptibility, oncogene activation and/or tumor suppressor gene alteration, with an irregular expression of the appropriate products [9]. The results of our study therefore provide evidence that plasma IgA and IgM levels are related to the etiology or clinical course of breast cancer, suggesting a disturbance in the immune system and immune dysfunction even when the cancer is localized to the breast. One of the fundamental arguments of these antibodies that interact with

Bovine serum albumin in patient with breast cancer initiated a controversial debate on the value of BSA antibodies as a tumor marker and on the role of BSA in breast cancer. Overall, we analyzed a high frequency of BSA/antibody cross effect among breast cancer individuals. We explored the contribution of this problem of immunoprecipitation with Bovine serum albumin in understanding the fundamental interaction patterns in tumors so that plasma will have only our antigen specific antibody. Plasma samples were preabsorbed with Bovine serum albumin to eliminate this interaction. After elimination of antibodies that interact with BSA, both immunoglobulin A and $M$ concentration confirm to be comparable between the affected and unaffected individual grouping (Tables 6,7 ). The successful results obtained in plasma of patients with breast cancer may reflect the increased creation of autoantibodies and then, direct to humoral immune defectiveness. This is best explained by suggesting that there is an interaction producing spurious immuno-precipitation as well as a circulating immunoglobulin which is capable of binding other autologous immunoglobulins which may well interact with other immune factor leading to abnormal humoral immune response $[10,35]$. There are also a number of constituents that address the development to autoimmunity as environmental,

Table 6: Effects of BSA pretreatment on plasma IgA level in groups of breast cancer patients and unaffected control.

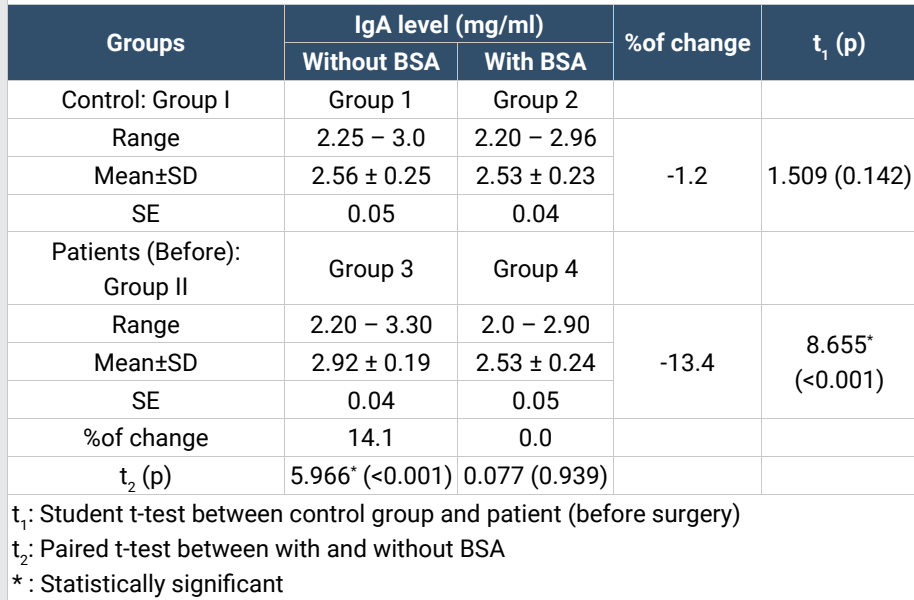

Table 7: Effects of BSA pretreatment on plasma IgM level in groups of breast cancer patients and unaffected control.

\begin{tabular}{|c|c|c|c|c|}
\hline \multirow{2}{*}{ Groups } & \multicolumn{2}{|c|}{ IgM level (mg/ml) } & \multirow{2}{*}{ \%sof change } & \multirow{2}{*}{$t_{1}(p)$} \\
\hline & Without BSA & With BSA & & \\
\hline Control: Group I & Group 1 & Group 2 & & \\
\hline Range & $1.50-2.0$ & $1.50-2.0$ & \multirow{3}{*}{-0.6} & \multirow{3}{*}{$1.253(0.220)$} \\
\hline Mean $\pm S D$ & $1.75 \pm 0.14$ & $1.74 \pm 0.15$ & & \\
\hline SE & 0.03 & 0.03 & & \\
\hline $\begin{array}{c}\text { Patients (Before): } \\
\text { Group II }\end{array}$ & Group 3 & Group 4 & & \\
\hline Range & $1.50-2.30$ & $1.50-1.90$ & \multirow{3}{*}{-15.8} & \multirow{3}{*}{$\begin{array}{l}10.172^{*} \\
(<0.001)\end{array}$} \\
\hline Mean $\pm S D$ & $2.02 \pm 0.14$ & $1.70 \pm 0.13$ & & \\
\hline SE & 0.03 & 0.03 & & \\
\hline \%difference & 15.4 & -2.3 & & \\
\hline$t_{2}(p)$ & $\begin{array}{c}6.711^{*} \\
(<0.001)\end{array}$ & $\begin{array}{c}0.808 \\
(0.423)\end{array}$ & & \\
\hline \multicolumn{5}{|c|}{$\begin{array}{l}\mathrm{t}_{2}: \text { Paired t-test between with and without BSA } \\
\star: \text { Statistically significant }\end{array}$} \\
\hline
\end{tabular}

Citation: Sabra SA, Saad AA, Abd El Moneim NA, El Atty Hemida MA, Haroun M, et al. (2020) Evaluation of breast cancer regarding molecular and immunochemica markers. Int J Immunother Cancer Res 6(1): 001-009. DOI: https://dx.doi.org/10.17352/2455-8591.000021 
genetic or immune disorders. Hormonal factors also have been included among events triggering autoimmunity or immune dysfunction. This combined fact highlights the involvement between autoimmunity and cancer [36,37]. This field of study reveals that there are autoantibodies in the plasma of patient with breast cancer that interrelate with Bovine serum albumin. In this paper we try to use Bovine serum albumin probabilistic interaction model as a tool risk of infection factor for breast cancer and in indicating this disease at-risk populations. By focusing on this paper we develop and tested a predictable marker that can be used in clinical laboratories as a supernumerary competent tool for diagnosis of breast cancer.

\section{References}

1. Kumar RM (2009) The widely used diagnostics DNA microarray a review. Am $\mathrm{J}$ Inf Dis 5: 207-218. Link: http://bit.ly/3bPuBum

2. Antoniu A, Pharuah PD, Risch HA, Eyfjord JE, Hopper JL (2003) Average risks of breast and ovarian cancer associated with BRCA1 or BRCA2 mutations detected in case series unselected for family history: A combined analysis of 22 studies. Am J Hum Genet 72: 1117-1130. Link: http://bit.ly/2vlqa43

3. Weinberg RA (1991) Tumor suppressor genes. Science 254: 1138-1146. Link http://bit.ly/2V5T3I6

4. Bacus SS, Gudkov AV, Esteva FJ, Yarden Y (2000) Expression of erb- B receptors and their ligands in breast cancer: implications to biological behavior and therapeutic response. Breast Dis 11: 63-75. Link: http://bit.ly/2SWS2sT

5. Esteva FJ, Sastry L, King CR (1998) The erbB-2 gene: from research to application, 421-444. In Hormones and Growth Factors in Development and Neoplasia, Dickson, R.B. and Salomon, D.S. (eds), John Wiley \& Sons, New York. Link: https://amzn.to/2uXQzuw

6. Esteva FJ, Pusztai L, Symmans WF, Sneige N, Hortobagi GN (2000) Clinical relevance of HER-2 amplification and overexpression in human cancers. Ref Gynecol Obst 7: 267-276. Link: http://bit.ly/37C815b

7. Van de Vijver MA (2000) Genetic alterations in breast cancer. Current Diagnostic Pathology 6: 271-281. Link: http://bit.ly/2P4UI6A

8. Boon $T$, van der Bruggen $P$ (1996) Human tumor antigens recognized by $T$ lymphocytes. J Exp Med 183: 725-729. Link: http://bit.ly/38Jag7Z

9. Castagnetta L, Granata OM, Traina A (2002) A role for sex steroids in autoimmune diseases: a working hypothesis and supporting data. Ann N Y Acad Sci 966: 193-203. Link: http://bit.ly/38BNoHv

10. Haroun M (2005) Bovine serum albumin antibodies as a disease marke for hepatitis $E$ virus infection. J Biomed Biotechnol 4: 316-321. Link: http://bit.ly/2V6hvDc

11. Haroun M, El-Sayed MM (2007) Measurement of IgG levels can serve as a biomarker in newly diagnosed diabetic children. J Clin Biochem Nutr 40: 56 61. Link: http://bit.ly/2SF3zy2

12. Haroun M (2007) Utility of bovine serum albumin antibodies as a biomarker for arthritis in children. Acta Med Nagasaki 52: 79-82. Link: http://bit.ly/2V3xKkd

13. Haroun M (2005) Effect of anti-immunoglobulin antibodies provides new insights into immune response to HCV. J Med Invest 52: 172-177. Link: http://bit.ly/2P8ygcT

14. Singh KP, Roy D (2001) Identification of novel breast tumor-specific mutation(s) in the q11.2 region of chromosome 17 by RAPD/AP-PCR fingerprinting. Gene 269: 33-43. Link: http://bit.ly/2SVNenQ

15. Sambrook J, Frisch EF, Maniatis T (1989) Molecular cloning: A Laboratory Manual, $2^{\text {nd }}$ edition. Cold spring Harbor laboratory press, New York.
16. Saad AA, Youssef M, El-Shennawy LK (2009) Cisplatin induced damage in kidney genomic DNA and nephrotoxicity in male rats: the protective effect of grape seed proanthocyanidin extract. Food Chem Toxicol 47: 1499-1506. Link: http://bit.ly/37F0diU

17. Engvall E, Perlmann P (1971) Enzyme-linked immunosorbent assay (ELISA): quantitative assay of immunoglobulin G Immunochem 8: 871-874.

18. Engvall E (1977) Quantitative enzyme immunoassay (ELISA) in microbiology. Med Biol 55: 193-200. Link: http://bit.ly/39NZfCA

19. Haroun M (2002) Effect of anti-immunoglobulin antibodies on serum IgA in type 1 diabetes mellitus. Bulletin of Alexandria Faculty of Medicine 35: 169174

20. Boysen L, Viuff BM, Landsy LH, Price SA, Raymond JT, et al. (2019) Formation and glomerular deposition of immune complexes in mice administered bovine serum albumin: Evaluation of dose, frequency, and biomarkers. J Immunotoxicology 16: 191-200. Link: http://bit.ly/2PmNrQ3

21. Atienzar FA Jha AN (2006) The random amplified polymorphic DNA (RAPD) assay and related techniques applied to genotoxicity and carcinogensis studies: A critical review. Mutat Res 613: 76-102. Link: http://bit.ly/2P7VS1I

22. Ali BA (2003) Detection of DNA alteration in abnormal phenotype of broile chicken male by random amplified polymorphic DNA (RAPD). Afric $\mathrm{J}$ Biotech 2: 153-156. Link: http://bit.ly/2wpFJxD

23. Lee YC, Yang VC, Wang TS (2007) Use of RAPD to detect sodium arseniteinduced DNA damage in human lymphoblastoid cells. Toxicol 239: 108-115 Link: http://bit.ly/32cPmv

24. Kumar A, Tyagi MB, Jha PN (2004) Evidences showing ultraviolet-B radiationinduced damage of DNA in cyanobacteria and its detection by PCR assay Biochem Biophys Commun 318: 1025-1030. Link: http://bit.ly/326B3Zi

25. Morimotor K, Wolf S, Kovzumi A (2003) Induction of sister-chromatid exchanges in human lymphocytes by microsomal activation of benzene metabolites Mut Res 119: 355-360. Link: http://bit.ly/2TauVLR

26. Xian ZH, Cong WM, Zhang SH, Wu MC (2005) Genetic alterations of hepatocellular carcinoma by random amplified polymorphic DNA analysis and cloning sequencing of tumor differential DNA fragment. World J Gastroenterol 11: 4102-4107. Link: http://bit.ly/326Mwbo

27. Elias AK, Alsabti MD (1979) Serum immunoglobulins in breast cancer. Journa of Surgical Oncology 11: 129-133. Link: http://bit.ly/2vIDsgX

28. Dostalova O, Schon F, Wagnerova M, Jelined J, Wanger V (1975) Serum immunoglobulin levels in cancer patients. Neoplasma 22: 539-546. Link: http://bit.ly/2VbIM82

29. Springer GF, Desai PR, Scanlon EF (1976) Blood group MN precursors as human breast carcinoma-associated antigens and naturally occurring human cytoxins against them. Cancer 37: 169-176. Link: http://bit.ly/39NqBZm

30. Simonte SJ, Cunningham-Rundles C (2003) Update on primary immunodeficiency: defects of lymphocytes. Clin Immunol 109: 109-118. Link: http://bit.ly/2P5flu2

31. Wang DY, Goodwin PR, Bulbrook RD, Hayward JL (1977) Plasma immunoglobulin levels in patients with breast cancer. Cancer 39: 2190-2193. Link: http://bit.ly/2V31WvJ

32. Roberts MN, Bathgate EM, Stevenson A (1975) Serum immunoglobulin levels in patients with breast cancer. Cancer 36: 221-224. Link: http://bit.ly/328mt3y

33. Qiu J, Keyser B, Lin ZT, Wu T (2018) Autoantibodies as Potential Biomarkers in Breast Cancer. Biosensors (Basel) 8: 67. Link: http://bit.ly/2wviMJE

34. Brockhoff G (2019) Target HER four in breast cancer? Oncotarget 10: 31473150. Link: http://bit.ly/38Gqe2T

Citation: Sabra SA, Saad AA, Abd El Moneim NA, El Atty Hemida MA, Haroun M, et al. (2020) Evaluation of breast cancer regarding molecular and immunochemical markers. Int J Immunother Cancer Res 6(1): 001-009. DOI: https://dx.doi.org/10.17352/2455-8591.000021 
35. Haroun M, El-Masry MH (2008) Antibodies reacting with human immunoglobulin in sera from autoimmune thyroid disease patients as a risk factor for false positive results in IgA assessment. Central European Journal of Immunology 33: 208-212. Link: http://bit.ly/32a8t9B

36. Jonsson V, Wiik A, Hou-Jensen K (1999) Autoimmunity and external lymphocytic infiltrations in lympho-proliferative disorders. J Intern Med 245 277-286.

37. Giat E, Ehrenfeld M, Shoenfeld Y (2017) Cancer and Autoimmune Diseases. Autoimmun Rev 16: 1049-1057. Link: http://bit.ly/39QyayH
Discover a bigger Impact and Visibility of your article publication with

\section{Peertechz Publications}

\section{Highlights}

* Signatory publisher of ORCID

* Signatory Publisher of DORA (San Francisco Declaration on Research Assessment)

* Articles archived in worlds' renowned service providers such as Portico, CNKI, AGRIS, TDNet, Base (Bielefeld University Library), CrossRef, Scilit, J-Gate etc.

* Journals indexed in ICMJE, SHERPA/ROMEO, Google Scholar etc.

* OAI-PMH (Open Archives Initiative Protocol for Metadata Harvesting)

* Dedicated Editorial Board for every journal

* Accurate and rapid peer-review process

* Increased citations of published articles through promotions

* Reduced timeline for article publication

Submit your articles and experience a new surge in publication services

(https://www.peertechz.com/submission).

Peertechz journals wishes everlasting success in your every endeavours.

Copyright: @ 2020 Sabra SA, et al. This is an open-access article distributed under the terms of the Creative Commons Attribution License, which permits unrestricted use, distribution, and reproduction in any medium, provided the original author and source are credited.

Citation: Sabra SA, Saad AA, Abd El Moneim NA, El Atty Hemida MA, Haroun M, et al. (2020) Evaluation of breast cancer regarding molecular and immunochemical markers. Int J Immunother Cancer Res 6(1): 001-009. DOI: https://dx.doi.org/10.17352/2455-8591.000021 